\title{
PHARMACEUTICALS IN THE GROUNDWATER OF THE INFORMAL SETTLEMENT "LAS FINCAS" ON COZUMEL ISLAND, MEXICO
}

\author{
CHRISTIAN KOCH ${ }^{1}$, OSCAR FRAUSTO MARTÍNEZ ${ }^{2}$, STEFFEN GIESE ${ }^{3}$, MATTHIAS SCHIRMER ${ }^{1}$, \\ DANIEL RAABE ${ }^{4}, \mathrm{SABINE} \mathrm{GEI}^{3}$ \& UWE MÜNCH ${ }^{3}$ \\ ${ }^{1}$ University of Applied Sciences Jena, Germany \\ ${ }^{2}$ University of Quintana Roo, Mexico \\ ${ }^{3}$ Thuringian Regional Office for Environment and Geology, Germany \\ ${ }^{4}$ Friedrich-Schiller-University Jena, Germany
}

\begin{abstract}
The consequences of informal urbanization and the practice of pumping domestic sewage from municipality into deeper zones of the subsoil may result in anthropogenic contamination of groundwater resources by feces and pharmaceuticals on Cozumel Island, Mexico. In order to estimate the extent of this environmental impact there was long term monitoring established in 10 domestic wells in the informal settlement "Las Fincas". Fecal contamination in all domestic wells indicated leaky septic tanks and the high porosity of the substrate.

Water samples were taken in domestic wells and the municipal sewage plant. A combined liquid chromatography and mass spectrometry procedure (HPLC-MS-qToF) was applied in order to detect potential contaminants in water. The analysis was carried out by a suspected-target-screening Letzel et al. [1]. Based on high resolution mass spectra and library search several substances were indicated. In the sample of the sewage plant substances like pharmaceuticals, herbicides and pesticides were detected. This means that these substances are continuously pumped into the aquifer. The actual situation presents a health risk for the inhabitants of "Las Fincas". Furthermore, the marine environment is in danger which has an extraordinary importance for the tourism-based economy of the island. It is recommended to stop the actual practice of wastewater grouting and replace it by a sustainable concept of wastewater treatment and disposal.
\end{abstract}

Due to the dilution processes in the karstic aquifer together with the limited detection capability of the method none of the substances could be detected in the domestic wells up to now. However, investigations by Metcalfe et al. [2] and Paul et al. [3] prove the disadvantageous impacts on groundwater that results from pumping wastewater in deeper zones of the aquifer. Therefore, the longterm monitoring shall be continued and investigation on groundwater extended to remoter parts of Cozumel.

Keywords: informal urbanization, contamination of groundwater, pharmaceuticals, long term monitoring.

\section{INTRODUCTION}

Cozumel Island is part of the Yucatec carbonate platform and is mainly composed of limestone (Fig. 1). Dissolution processes in the limestone lead to karstification. Groundwater preferentially flows into karstic cavities and tunnel systems. Due to its permeable structure the karstic aquifer shows a high vulnerability to anthropogenic impacts.

Cozumel Island has a total area of 478 square kilometers [4], its aquifer extends into an area of 263 square kilometers [5]. The groundwater is or stands in direct contact with the sea water. The lower density of the freshwater causes the freshwater lens to rest on the surrounding salt water [6]. The hydrometeorology shows the following characteristics (Hölting [7]: $\dot{h}_{\mathrm{N}}=\dot{h}_{\mathrm{Ao}}+\dot{h}_{\mathrm{Au}}+\dot{h}_{\mathrm{V}}$ ): 


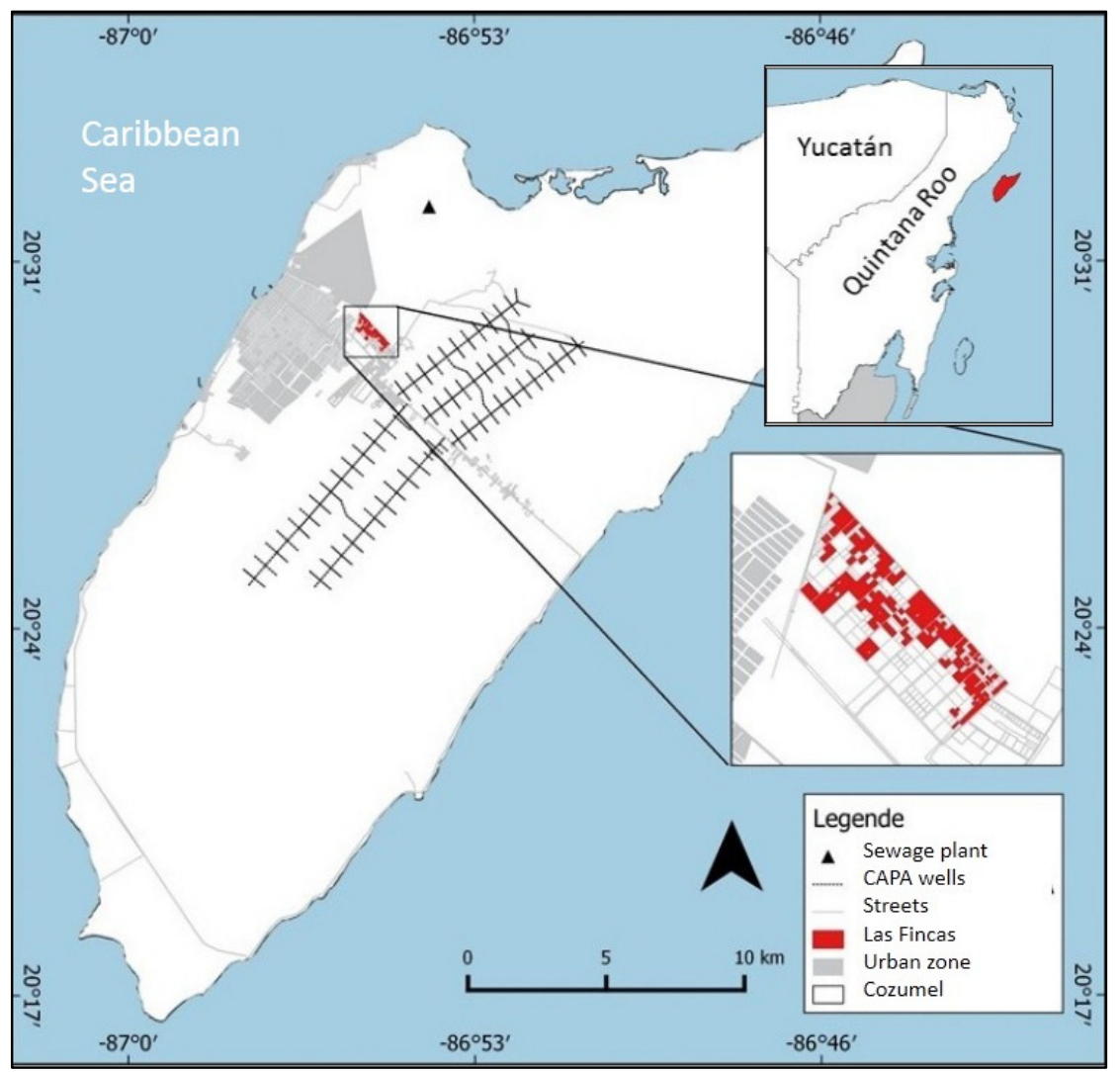

Figure 1: Location of "Las Fincas” and Cozumel's municipal sewage plant.

- $\quad$ average annual precipitation 1175 millimeters [8],

- 75 percent evapotranspiration, 19 percent superficial drainage and 6 percent underground discharge [9],

- an average annual groundwater recharge of 47.5 million cubic meters [5].

CAPA (Comisión de Agua Potable y Alcantarillado) is responsible for the water supply of Cozumel. 151 wells in the center of the island are used for the production of potable water which has increased in the last decades from 1.9 in 1986 to 3.5 million cubic meters in 2015 [8]. Further investigations discovered the practice of the grouting of treated wastewater by the local water supplier in the north of Cozumel Island about 6 kilometers away from "Las Fincas". CAPA grouts about 1.7 million cubic meters in 105 meters depth into the aquifer which presents 3.5 percent of the annual groundwater recharge of Cozumel Island [10].

\section{2 "LAS FINCAS"}

The informal settlement "Las Fincas" is situated in the outskirts of the municipality San Miguel de Cozumel (Fig. 1). Due to the informal urbanization there is neither water or power supply nor a sewerage nor waste disposal system. House construction and inhabitation of parceled lots take place without any official control (Fig. 2(a) and 2(b)). Streets are not paved 
(Fig. 3(a)). The residents of "Las Fincas" obtain water from domestic wells (Fig. 3(b)). Wastewater is collected in cisterns and caverns.

Due to the encountered and documented situation relating the not existing sewerage and waste disposal and the missing infrastructure for water supply the focus of the present investigation was placed on the groundwater quality of the area. With the help of a survey it was possible to get an overview of the settlement which presented the following results:

- 400 lots in total with about 1000 residents;

- 250 domestic wells;

- 180 non-drained wastewater storage basins;

- infrequent waste disposal of private of the waste management company PASA (Promotora Ambiental de la Laguna) (Fig. 3(a));

- waste is stored on the lots and sometimes burned.
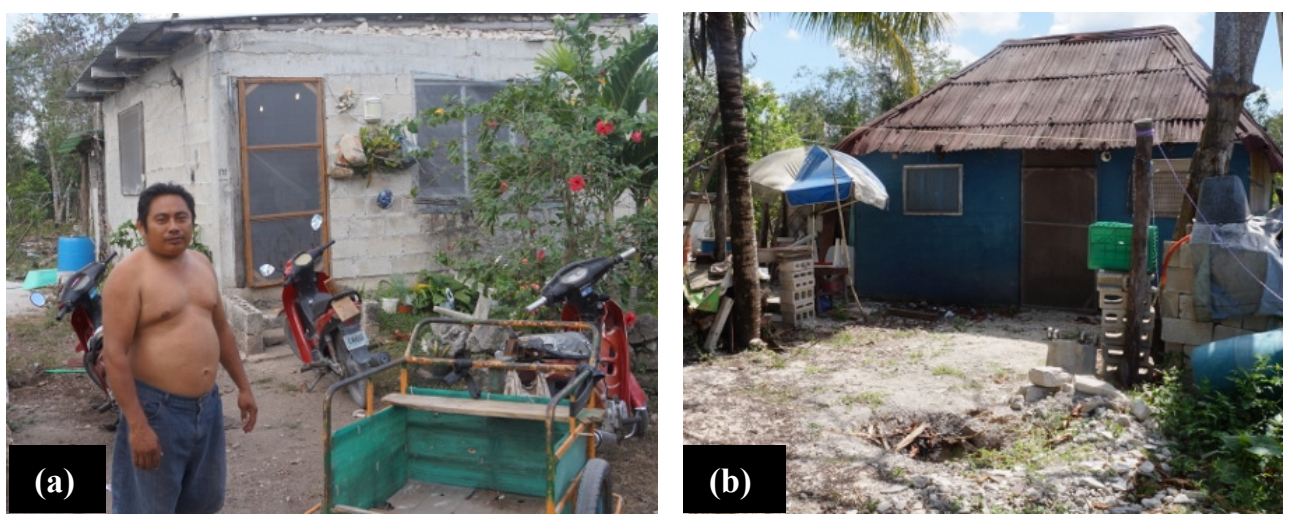

Figure 2: Housing conditions in "Las Fincas": (a) resident in front of his house; (b) residential building.
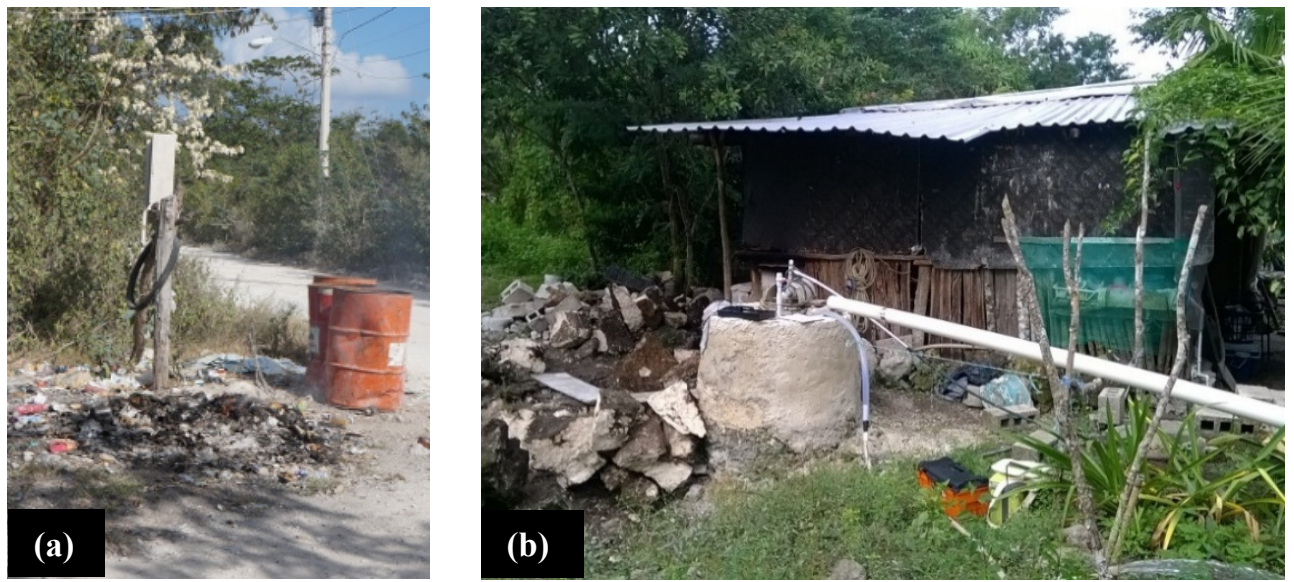

Figure 3: Housing conditions in "Las Fincas": (a) burned waste on the street; (b) residential building with domestic well. 
It was presumed that the inconsequent waste management and inappropriate storage and disposal of waste caused a contamination of the karstic aquifer. The sewage plant of Cozumel is located about six kilometers north of "Las Fincas".

\section{FLOW SYSTEMS IN KARST}

Karst is Serbo-Croatian and comes from the mountains of the same name in the Slovenian Adria. Karst describes the formations that grew by corrosion of solvable rocks. This process leads to karstification which is typical for carbonate rocks (particularly limestone) and evaporates. Corrosion of carbonate takes place when water $\left(\mathrm{H}_{2} \mathrm{O}\right)$ and carbon dioxide $\left(\mathrm{CO}_{2}\right)$ of the air react to carbon acid $\left(\mathrm{H}_{2} \mathrm{CO}_{3}\right)$. After that carbon acid reacts with Carbonate to hydrocarbonate, e.g. $\mathrm{Ca}\left(\mathrm{HCO}_{3}\right)^{2}$ which dissociates in water (equation 1).

$$
\mathrm{CaCO}_{3}+\mathrm{H}_{2} \mathrm{CO}_{3} \leftrightarrow \mathrm{Ca}\left(\mathrm{HCO}_{3}\right)_{2} \leftrightarrow \mathrm{Ca}^{2+}+2 \mathrm{HCO}_{3}^{-}
$$

The reason for the intensive solution processes in humid tropic climates are higher temperatures, precipitation rates, carbon dioxide contents and acids that arise from fast dissociation of organic compounds. Typical karst formations are:

a) Surface reliefs (e.g. limestone pavement, sinkholes, Polje)

b) Subterranean dissolutions forms (e.g. caverns, holes)

c) Creation of precipitation (e.g. dripstones)

d) Hydrography characterized by subterranean drainage (karst hydrography) [11].

\subsection{Hydrological conditions of Cozumel}

The island is made of reefs which date from the Oligocene and the Quaternary ages. Carbonate rocks have been exposed to karstification since their creation and formed a karstic aquifer. Only small parts of the karst system are investigated and documented by professional cave divers. These parts are used by tourism.

The karst of Cozumel is characterized by sinkholes without surface drainage. Sinkholes are called "cenotes". Subterranean discharge takes place in widely ramified cavern systems. Discharge is always directed to the sea. Due to the widely-ramified caverns discharge can cover long distances by low slopes in the underground [9].

\section{METHODS AND MATERIAL}

The groundwater sampling was carried out in October 2016 in 10 domestic wells in the informal settlement "Las Fincas". The selection of the domestic wells was done according to accessibility, productiveness, naturalness of the well and consumption behavior of the owners and was determined in a previous investigation (January to March 2016). In addition, one sample was taken from the discharge of the sewage plant of Cozumel, located about six kilometers from the settlement.

At the beginning of the sampling standing water was pumped out of the well for 20 minutes via a five to 10 meters long hose. Thereby direct return flow could be avoided. Once parameters were stable, temperature, $\mathrm{pH}$, electrical conductivity and oxygen concentration were measured by the YSI Pro Plus probe (Fig. 4). Then samples were taken and filled in special vessels. Besides the mentioned physico-chemical parameters heavy metals as e.g. aluminum, copper, lead and zinc were analyzed in laboratory. 


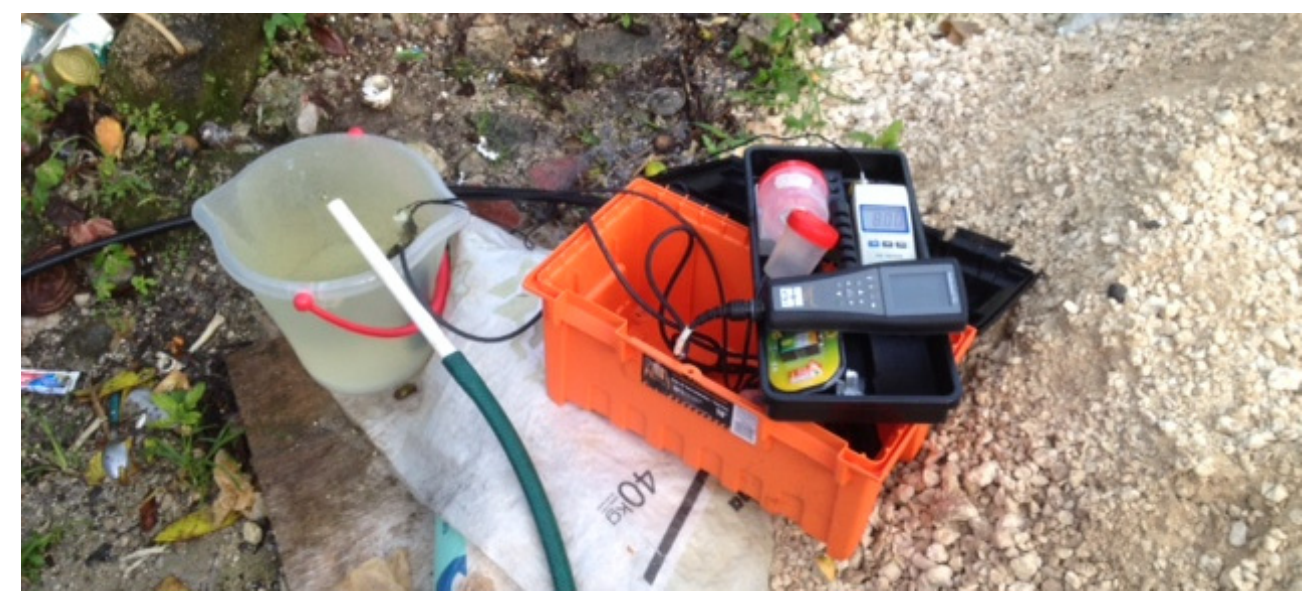

Figure 4: Set-up for measurement of insitu-parameters in "Las Fincas".

The samples were analysed by a suspected-screening method [12] using High Performance Liquid Chromatography (HPLC) coupled with a tandem Time-of-Flight mass-spectrometer (qToF). The liquid chromatography system "Nexera X2 (Shimadzu)", and the massspectrometer "MS-qToF-System Triple-TOFTM 5600 AB Sciex" were used. The chromatograph separates mixtures of substances into individual analytes. For each sample there was carried out a triple-way analysis in positive and negative ionization mode via electrospray ionization (ESI).

Suspected-target-screening is a method which allows for searching of a certain amount of substances which are themselves available in mass spectrometric libraries. The library used here has 10,354 records. The analysis was performed by MasterView 1.1. For an additional plausibility check a combined assessment was used by means of the database FOR-IDENT. As samples were collected in plastic tubes and for this reason potential contamination by the plastic material could not be avoided there was generally realized a comparison with a blank test. The applied analytical method was developed in detail by Raabe [12].

The results of such a suspect-target screening without verifying by real standard substances are a qualified indication of the substances. That means, the advantage of the method, searching for around 10,000 substances is coupled with two disadvantages: The results based on high resolution MS/MS spectra are relatively reliable, but not with $100 \%$. Another disadvantage is the concentration range in which the substances will be detected. This is around 0.1 to $10 \mu \mathrm{g} / \mathrm{l}$ depending on the ionization and mass spectrometric fragmentation properties of the individual substances. Compared with target analytical methods with detection limits of around $0.001-0.1 \mu \mathrm{g} / 1$ suspect target analysis is not as good concerning the detection limits.

\section{RESULTS}

\subsection{Physico-chemical parameters and heavy metals}

The results of the physico-chemical parameters as well as heavy metals rarely showed differences in their spectrum. The anthropogenic contamination of the groundwater was indicated. Nitrate $(10 \mathrm{mg} / \mathrm{l})$ concentration exceeded in one domestic well the limits of the 
Mexican norm for drinking water (NOM-127-SSA1-1994 from 22.11.2000). The results did not indicate the intrusion of sea water. Drain water of the sewage plant showed high saline concentration and turbidity. Heavy metals did not exceed existing limits for drinking water. In one domestic well zinc concentration showed a higher value $(204.5 \mu \mathrm{g} / \mathrm{l})$ above the minor threshold value $58 \mu \mathrm{g} / \mathrm{l}$ of the German interstate working group for water (LAWA) which proves anthropogenic impacts (Table 1) [13].

\subsection{Suspected-target-screening}

In the discharge of the sewage plant 61 substances could be detected. Substances can be classified in pharmaceuticals (e.g. antibiotics Sulfmethoxazole and Trimethoprim, Carbamazepine, Diclofenac), herbicides (e.g. Cyanazine, Choridazon, Bromazil) and pesticides (e.g. Triazophos, Chlorpyrifos, Coumaphos) (Fig. 5, Fig. 6 and Table 2). Detected insecticides are an evidence of the large-scale application for mosquito protection.

In the domestic wells no substances were detected due to the limited detection strength of the method. This means, that a target analysis with better detection limits should be performed.

\section{INTERPRETATION}

The results of the screening (pharmaceuticals, herbicides, pesticides) show clearly that these substances (Table 2) are with a high probability an integral part of the discharge of the sewage plant. These substances are pumped with the treated wastewater into the aquifer. Due to high dilution processes in the karstic aquifer the substances could not be detected by suspected target means in the domestic wells. This can result in a harmful impact on groundwater, similar to the investigations of Metcalfe et al. [2] and Paul et al. [3] evidence the negative impact on the aquifers in Playa del Carmen, Mexico and Florida, USA caused by grouting of municipal wastewater. This previously common practice in Florida and other US states has been prohibited by the authorities due to its harmful impact on groundwater.

Table 1: Selected measurement results for physico-chemical parameter and heavy metals.

\begin{tabular}{|l|c|c|c|c|c|c|c|c|}
\hline \multirow{2}{*}{ Parameter } & \multirow{2}{*}{ Unit } & \multicolumn{7}{|c|}{ Number of well } \\
\cline { 3 - 9 } & & 1322 & 921 & 905 & 941 & 1008 & 904 & $\begin{array}{c}\text { Sewage } \\
\text { plant }\end{array}$ \\
\hline Temp. & ${ }^{\circ} \mathrm{C}$ & 25.8 & 25.5 & 25.7 & 26.2 & 26 & 26.3 & 31.3 \\
\hline $\mathrm{pH}$ & & 7.7 & 7.51 & 8.07 & 7.54 & 7.49 & 7.25 & 8.2 \\
\hline $\mathrm{Conduct.}$ & $\mu \mathrm{S} / \mathrm{cm}$ & 543 & 573 & 380 & 793 & 1240 & 824 & 2830 \\
\hline $\mathrm{O}_{2}$ & $\mathrm{mg} / 1$ & 0.82 & 0.63 & 1.42 & 0.85 & 2.16 & 0.77 & 2.27 \\
\hline $\mathrm{Cl}^{-}$ & $\mathrm{mg} / 1$ & 29.6 & 33.3 & 25.1 & 46 & 90.1 & 48.3 & 553 \\
\hline $\mathrm{NO}_{3}$ & $\mathrm{mg} / 1$ & 0.231 & 0.34 & $<0.15$ & 1.271 & 17.587 & 2.702 & $<0.15$ \\
\hline $\mathrm{NO}_{2}$ & $\mathrm{mg} / 1$ & 0.031 & $<0.001$ & 0.01 & 0.03 & 0.107 & 0.004 & 0.226 \\
\hline $\mathrm{Al}$ & $\mu \mathrm{g} / 1$ & $<5.00$ & $<5.00$ & 6.85 & $<5.00$ & $<5.00$ & $<5.00$ & 34.4 \\
\hline $\mathrm{Cu}$ & $\mu \mathrm{g} / 1$ & 3.949 & 5.44 & $<0.500$ & 1.388 & 1.209 & 5.281 & 3.376 \\
\hline $\mathrm{Zn}$ & $\mu \mathrm{g} / 1$ & 2.147 & 4.593 & 1.136 & 7.625 & 204.5 & 11.48 & 8.846 \\
\hline $\mathrm{Pb}$ & $\mu \mathrm{g} / 1$ & 0.281 & $<0.15$ & $<0.15$ & $<0.15$ & $<0.15$ & $<0.15$ & 0.181 \\
\hline
\end{tabular}




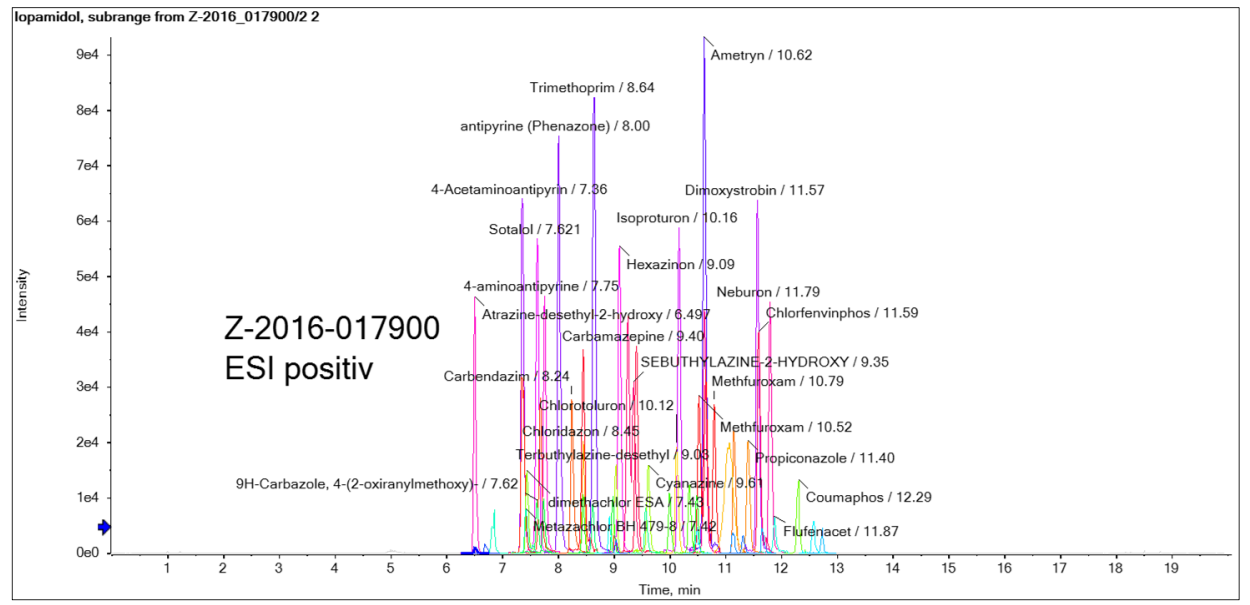

Figure 5: Extracted ion chromatogram (XIC) for detected substances of the sample "discharge sewage plant" (ESI positive).

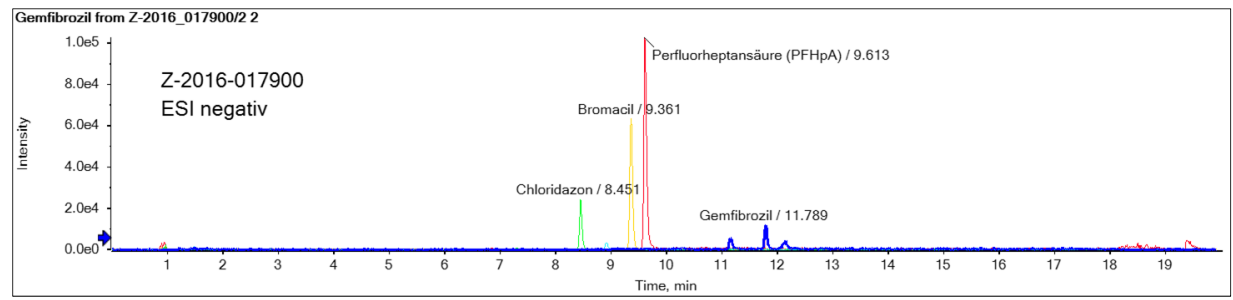

Figure 6: Extracted ion chromatogram (XIC) for detected substances of the sample "discharge sewage plant" (ESI negative).

There is intended to realize a quantitative analysis of the grouted wastewater for the next sample campaign on Cozumel Island in order to determine exact concentrations of pharmaceuticals and other substances. As a next step the domestic wells of the long-term monitoring and wastewater will be tested for streptococcus. Bacteria showed high suitability as indicator for anthropogenic impacts on groundwater [14].

\section{CONCLUSION}

Samples of 10 domestic wells in "Las Fincas" and the discharge of the municipal sewage plant were taken and examined by a suspected-target-screening. Pharmaceuticals, herbicides and pesticides verifiable reach the groundwater of Cozumel Island due to the municipal practice of grouting of treated wastewater. This leads to a negative impact on the aquifer which can also affect the marine environment.

The actual situation creates health risks for the inhabitants of "Las Fincas" and Cozumel. Furthermore, environmental damage caused by polluted water endanger the long-term development of the important touristic sector. The practice of the grouting of treated wastewater shall be replaced by a sustainable concept for wastewater treatment and disposal. 
Table 2: Detected substances in the discharge of the sewage plant.

\begin{tabular}{|c|c|c|c|}
\hline Library hit & Molecular formula & $\begin{array}{c}\text { No. } \\
\text { of } \\
\text { "N"* }\end{array}$ & $\begin{array}{c}\text { Database-confirmation for } \\
\text { substance(FOR-IDENT) } \\
\text { + positive, - negative }\end{array}$ \\
\hline \multicolumn{4}{|l|}{ Results ESI positive } \\
\hline 4-Acetaminoantipyrin & $\mathrm{C} 13 \mathrm{H} 15 \mathrm{~N} 3 \mathrm{O} 2$ & 3 & + \\
\hline 4-Aminoantipyrine & $\mathrm{C} 11 \mathrm{H} 13 \mathrm{~N} 3 \mathrm{O}$ & 3 & + \\
\hline 4-Formylaminoantipyrin & $\mathrm{C} 12 \mathrm{H} 13 \mathrm{~N} 3 \mathrm{O} 2$ & 3 & + \\
\hline Ametryn & C9H17N5S & 3 & + \\
\hline Antipyrine (Phenazone) & $\mathrm{C} 11 \mathrm{H} 12 \mathrm{~N} 2 \mathrm{O}$ & 3 & + \\
\hline Atrazin-desisopropyl & C5H8ClN5 & 3 & + \\
\hline Atrazine-2-hydroxy & $\mathrm{C} 8 \mathrm{H} 15 \mathrm{~N} 5 \mathrm{O}$ & 3 & + \\
\hline Atrazine-desethyl & C6H10CIN5 & 3 & + \\
\hline Atrazine-desethyl-2-hydroxy & C6H11ON5 & 3 & + \\
\hline Azinphos-ethyl & $\mathrm{C} 12 \mathrm{H} 16 \mathrm{~N} 3 \mathrm{O} 3 \mathrm{PS} 2$ & 3 & + \\
\hline Bezafibrate & C19H20CINO4 & 3 & + \\
\hline Butoxamine & $\mathrm{C} 15 \mathrm{H} 25 \mathrm{NO} 3$ & 3 & - \\
\hline Carbamazepine & $\mathrm{C} 15 \mathrm{H} 12 \mathrm{~N} 2 \mathrm{O}$ & 3 & + \\
\hline Carbendazim & $\mathrm{C} 9 \mathrm{H} 9 \mathrm{~N} 3 \mathrm{O} 2$ & 3 & - \\
\hline Chlorfenvinphos & $\mathrm{C} 12 \mathrm{H} 14 \mathrm{Cl} 3 \mathrm{O} 4 \mathrm{P}$ & 3 & + \\
\hline Coumaphos & C14H16C1O5PS & 3 & + \\
\hline Cyanazine & C9H13CIN6 & 3 & + \\
\hline Dapiprazole & $\mathrm{C} 19 \mathrm{H} 27 \mathrm{~N} 5$ & 3 & - \\
\hline Diclofenac & $\mathrm{C} 14 \mathrm{H} 11 \mathrm{Cl} 2 \mathrm{NO} 2$ & 3 & + \\
\hline Dimethachlor ESA & C13H19NO5S & 3 & + \\
\hline Dimoxystrobin & $\mathrm{C} 19 \mathrm{H} 22 \mathrm{~N} 2 \mathrm{O} 3$ & 3 & + \\
\hline Diuron & $\mathrm{C} 9 \mathrm{H} 10 \mathrm{Cl} 2 \mathrm{~N} 2 \mathrm{O}$ & 3 & + \\
\hline Epoxiconazol & $\mathrm{C} 17 \mathrm{H} 13 \mathrm{ClFN} 3 \mathrm{O}$ & 3 & + \\
\hline Flufenacet & $\mathrm{C} 14 \mathrm{H} 13 \mathrm{~F} 4 \mathrm{~N} 3 \mathrm{O} 2 \mathrm{~S}$ & 3 & + \\
\hline Hexazinon & $\mathrm{C} 12 \mathrm{H} 20 \mathrm{~N} 4 \mathrm{O} 2$ & 3 & + \\
\hline Isoproturon & $\mathrm{C} 12 \mathrm{H} 18 \mathrm{~N} 2 \mathrm{O}$ & 3 & + \\
\hline Mazindol & $\mathrm{C} 16 \mathrm{H} 13 \mathrm{ClN} 2 \mathrm{O}$ & 3 & - \\
\hline $\begin{array}{l}\text { Metazachlorsulfonsäure BH 479- } \\
8\end{array}$ & $\mathrm{C} 14 \mathrm{H} 17 \mathrm{~N} 3 \mathrm{O} 4 \mathrm{~S}$ & 3 & + \\
\hline Methyldesphenylchloridazon & $\mathrm{C} 5 \mathrm{H} 6 \mathrm{ClN} 3 \mathrm{O}$ & 3 & + \\
\hline Monolinuron & $\mathrm{C} 9 \mathrm{H} 11 \mathrm{CIN} 2 \mathrm{O} 2$ & 3 & + \\
\hline $\begin{array}{l}\text { N-[(2-methyl-5-nitrophenyl) } \\
\text { carbamothioyl] acetamide }\end{array}$ & $\mathrm{C} 10 \mathrm{H} 11 \mathrm{~N} 3 \mathrm{O} 3 \mathrm{~S}$ & 3 & + \\
\hline N-1-Acetylsulfamethoxazol & $\mathrm{C} 12 \mathrm{H} 13 \mathrm{~N} 3 \mathrm{O} 4 \mathrm{~S}$ & 3 & + \\
\hline Neburon & $\mathrm{C} 12 \mathrm{H} 16 \mathrm{Cl} 2 \mathrm{~N} 2 \mathrm{O}$ & 3 & + \\
\hline
\end{tabular}


Table 2: Continued

\begin{tabular}{|l|c|c|c|}
\hline Norclobazam & $\mathrm{C} 15 \mathrm{H} 11 \mathrm{ClN} 2 \mathrm{O} 2$ & 3 & + \\
\hline Propiconazole & $\mathrm{C} 15 \mathrm{H} 17 \mathrm{Cl} 2 \mathrm{~N} 3 \mathrm{O} 2$ & 3 & + \\
\hline Propyphenazone & $\mathrm{C} 14 \mathrm{H} 18 \mathrm{~N} 2 \mathrm{O}$ & 3 & + \\
\hline Sotalol & $\mathrm{C} 12 \mathrm{H} 20 \mathrm{~N} 2 \mathrm{O} 3 \mathrm{~S}$ & 3 & + \\
\hline Sulfaquinoxaline & $\mathrm{C} 14 \mathrm{H} 12 \mathrm{~N} 4 \mathrm{O} 2 \mathrm{~S}$ & 3 & - \\
\hline Terbuthylazine-desethyl & $\mathrm{C} 7 \mathrm{H} 12 \mathrm{ClN} 5$ & 3 & + \\
\hline Terbutryn & $\mathrm{C} 10 \mathrm{H} 19 \mathrm{~N} 5 \mathrm{~S}$ & 3 & + \\
\hline $\begin{array}{l}\text { Terbutylazine-desethyl-2- } \\
\text { hydroxy }\end{array}$ & $\mathrm{C} 7 \mathrm{H} 13 \mathrm{~N} 5 \mathrm{O}$ & 3 & - \\
\hline Triazophos & $\mathrm{C} 12 \mathrm{H} 16 \mathrm{~N} 3 \mathrm{O} 3 \mathrm{PS}$ & 3 & + \\
\hline Trimetazidine & $\mathrm{C} 14 \mathrm{H} 22 \mathrm{~N} 2 \mathrm{O} 3$ & 3 & - \\
\hline Results ESI negative & \multicolumn{2}{|c|}{} \\
\hline Perfluorheptansäure (PFHpA) & $\mathrm{C} 7 \mathrm{HF} 13 \mathrm{O} 2$ & 3 & + \\
\hline Bromacil & $\mathrm{C} 9 \mathrm{H} 13 \mathrm{BrN} 2 \mathrm{O} 2$ & 3 & + \\
\hline Gemfibrozil & $\mathrm{C} 15 \mathrm{H} 22 \mathrm{O} 3$ & 3 & + \\
\hline Sulfamethoxazol & $\mathrm{C} 10 \mathrm{H} 11 \mathrm{~N} 3 \mathrm{O} 3 \mathrm{~S}$ & 3 & + \\
\hline Chloridazon & $\mathrm{C} 10 \mathrm{H} 8 \mathrm{ClN} 3 \mathrm{O}$ & 1 & + \\
\hline * Number of approved screening criteria (retention time, isotope pattern, production spectrum).
\end{tabular}

\section{ACKNOWLEDGEMENTS}

The authors would like to thank Professor Adrián Cervantes-Martínez of the University of Quintana Roo (UQROO) for providing measuring equipment and the German Academic Exchange Service (DAAD) for the financial support to Christian Koch in form of a scholarship which made field work possible. Finally, this paper is the result of the academic exchange between the UQROO and the University of Applied Science (UAC) Jena as well as the TLUG. We thank these institutions and all responsible persons for their collaboration.

\section{REFERENCES}

[1] Letzel, T., Bayer, A., Schulz, W., Heermann, A., Lucke, T., Greco, G., Grosse, S., Schussler, W., Sengl, M. \& Letzel, M., LC-MS screening techniques for wastewater analysis and analytical data handling strategies: Sartans and their transformation products as an example. Chemosphere, 137, 198-206, 2015.

[2] Metcalfe, C.D., Beddwos, P.A., Gold Bouchot, G., Metcalfe, T.I., Li, H. \& Van Lavieren, H., Contaminants in the coastal karst aquifer system along the Carribean coast of the Yucatan Peninsula, Mexico. Environmental Pollution, 159, pp. 991-997, 2011.

[3] Paul, E., McLaughlin, M.R., Griffin, D.W., Lipp, E.K. \& Rose, J.B., Rapid movement of wastewater from on-site disposal systems into surface water in the Lower Florida Keys. Estuaries, 23, pp. 662-668, 2000.

[4] Escalante, P., Conabio: Portal de Geoinformación, 1996. Retrieved from Shapefile "Tipos de vegetación de la Isla de Cozumel, Quintana Roo": www.conabio.gob.mx/informacion/gis/

[5] Coral Zaragoza, E., Diagnóstico del Estado de Implementación del Indicador Grado de Presión Hídrico sobre el Acuífero de la Isla de Cozumel. pp. 90-91, 2015. 
[6] Lesser, H., Azpeita, J. \& Lesser, J., Geohidrología de la Isla de Cozumel. Q. Roo. Recursos Hidráulicos, 6(1), pp. 32-50. http://lesser.com.mx/files/78-1-GeohidrologiaIsla-de-Cozumel,-Q-Roo.pdf

[7] Hölting, B., Hydrogeologie: Einführung in die allgemeine und angewandte Hydrogeologie (4th edition), Stuttgart: Ferdinand Enke Verlag, 1992.

[8] Frausto Martínez, O., Rojas, J., Ihl, T. \& Morales, N., Atlas de riesgo, vulnerabilidad y peligros de la isla de Cozumel. Chetumal: D.R. Universidad de Quintana Roo, pp. 31-39, 2014.

[9] Wurl, J. \& Giese, S., Groundwater quality research on Cozumel Island, State of Quintana Roo, Mexico. In O. Frausto Martínez, Desarrollo sustentable: Turismo, costas y educación, Cozumel: Universidad de Quintana Roo, pp. 171-176, 2005.

[10] Telléz Diaz, Personal Communication, 16 March 2016, Head of Technical Maintenance, Comisión de Agua Potable y Alcantarillado (CAPA), Cozumel, Mexico.

[11] Spektrum der Wissenschaft Verlagsgesellschaft $\mathrm{mbH}$, Karst: Lexikon der Geowissenschaften. http://www.spektrum.de/lexikon/geowissenschaften/karst/8099

[12] Raabe, D., Suspected-Target-Screening von ausgewählten Thüringer Wässern mittels Kopplung von Hochleistungsflüssigchromatographie mit Tandem-Flugzeitmassenspektrometrie (LC-MS-qToF), Jena: Friedrisch-Schiller-Universität, pp. 4-18, 2016.

[13] Länderarbeitsgemeinschaft Wasser (LAWA), Ableitung von Geringfügigkeitsschwellenwerten für das Grundwasser, www.lawa.de/documents/ GFS-Bericht-DE_a8c.pdf. Accessed on: 20 March 2017.

[14] Koch, C., Frausto Martínez, O., Giese, S., Schirmer, M. \& Steenbeck, T., Impact on groundwater of a karstic aquifer in the informal settlement "Las Fincas" on Cozumel Island, Mexico, WIT Transactions on Ecology and the Environment, 203, WIT Press: Southampton and Boston, pp. 147-158, 2016. 